\title{
African Regional Trade Agreements and Intra-African Trade
}

\author{
Nicholas Ngepah \\ University of Johannesburg, Johannesburg, South Africa \\ Maxwell C. Udeagha \\ University of Johannesburg, Johannesburg, South Africa
}

\begin{abstract}
This paper investigates regional trade agreements in Africa by using panel data spanning 1995 2014. Trade creation and diversion effects are assessed through a gravity model estimated using the Eicker-White robust covariance Poisson pseudo-maximum likelihood method. This method proves superior to the usual nonlinear least square estimators, especially against heteroscedasticity and data with zero value. The findings suggest that regional trade agreements may enhance trade. The differences in effects can be matched with the effectiveness in implementation by respective member countries. The trade gains of regional trade agreements do not come at the expense of trade with non-members. By controlling for the duration within a regional trade agreement, we also show that a very small but significant share of the benefits occurs over time in the Economic and Monetary Community of Central Africa, Southern African Development Community, Southern African Customs Union, and West African Economic and Monetary Union. Trade benefits seem to decline over time in the East African Community.
\end{abstract}

\footnotetext{
* Corresponding Author: Nicholas Ngepah; University of Johannesburg, Department of Economics and Econometrics, P.O Box 524, Auckland Park, 2006, South Africa, Tel: +27733789075, E-mail: nngepah@uj.ac.za 
JEL Classification: F13, F15, C33, C30

Keywords: Regional Trade Agreements, Gravity Model, Trade Creation, Trade Diversion, African RTAs, Panel Data

\section{Introduction}

There is a consensus that developing countries would gain more from free trade (Huff 2000). Due to Africa's relatively low share in global trade, some have thought of RTAs in Africa as vehicles for the promotion of trade, regional economies of scale, and market access for sustained growth and development (Ogunkola 1998). However, the tradeenhancing benefits of RTAs are not straightforward. Bhagwati and Panagariya (1996) termed preferential trade agreements as two-faced because trade liberalization following RTAs may come at the cost of discrimination or trade diversion.

Viner (1950) was the first to describe the welfare effects of RTAs as a result of two opposing effects: trade creation and trade diversion. With the possibility of beneficial or harmful effects of RTAs, Magee (2008) concluded that the net effects must be guided by country-specific economic structures and evidence from the data. Although Africa has been ahead of the world regarding the number of existing RTAs, evidence of gains arising from these RTAs is mixed. This is partly because most studies have examined RTAs separately and the few that have compared multiple RTAs. With the advances in empirical methodologies and improvements in data, revisiting the effects of RTAs on trade flows in Africa becomes significantly important due to the very low levels of intraAfrican trade. This study contributes to the literature by examining a gravity model for panel data from 1995 to 2014 for 53 African countries.

The rest of the paper is organized as follows. Section II briefly discusses the progress made by the different RTAs in dismantling tariff barriers and trends in trade flows. Section III reviews the literature on RTAs and their implication on trade flows. Section IV discusses the analytical approaches. The results are presented in section $\mathrm{V}$, and section VI concludes with policy implications. 


\section{Tariff Reductions and Trade Flows}

Table 1 presents the extent to which regional trade blocs in Africa have made progress with respect to tariff reductions and the trade flow between 1995 and 2014. We arbitrarily divide the period into two sub-periods: 1995 2004 and 2005 2014. Then, we classify the regions into three groups: the high-low group comprises those with initially (1995 2004) high Most-Favored-Nation (MFN) treatment tariffs and which then proceeded to significant reductions in the later (2005 2014) period; the high-high group comprises those with persistently high tariffs in both periods; and the low-low group comprises those with low tariff rates in both periods.

The Common Market for Eastern and Southern Africa (COMESA), East African Community (EAC), Economic Community of West African States (ECOWAS), Southern African Development Community (SADC), Arab Maghreb Union (UMA), and Community of Sahel-Saharan States (CSSS) belong to the high-low class of tariff trends. These are RTAs whose member countries have followed through with RTA policy commitments by significantly reducing tariff barriers. These tariff reductions also correspond to increased intra-group flow in exports and imports over the two subperiods. For instance, COMESA had applied an average of 18\% tariff rate between member countries from 1995 to 2004. During this period, intra-COMESA exports and imports were about 1.7 billion US dollars and 1.9 billion US dollars, respectively. Following a decrease in this rate to $12 \%$ over the period 2005 2014, intra-COMESA exports and imports significantly increased to 7.5 billion US dollars and 8.0 billion US dollars, respectively. Similar trends are observed in all other RTAs in this class (Table 1).

The Central African Economic and Monetary Community (CEMAC), Economic Community of Central African States (ECCAS), and Inter-Governmental Authority on Development (IGAD) are grouped under the high-high tariff progression regions. These are regions whose member countries have seemingly not followed through in significantly dismantling tariff barriers. Correspondingly, these RTAs have not significantly improved their trade flows. Table 1 shows that although intra-regional exports and imports increased while tariff rates remained unchanged, these increases were very small. For instance, the CEMAC region maintained an 18\% MFN tariff rate over the two periods. Between 1995 and 2004, intra-CEMAC exports and imports were 155,321 US dollars and 196,377 US dollars, respectively; exports and imports were 727,494 US dollars and 949,359 US dollars, respectively, between 2005 and 2014. Other 
RTAs in this class also exhibit similar trends in trade flows. These regions have not successfully dismantled barriers to trade; hence, intra-regional trade is relatively low. It has been long established that tariff reductions between trading partners can induce trade in two ways (Head and Ries 1999). First, a reduction in a foreign partner's tariffs can enhance trade in a home country through the easy access to the market of the partner and competiveness of home goods in the foreign market. A reduction in the tariff levels of the home country has also been shown to be associated with scale expansion and hence more exports to meet foreign demands (Tybout et al, 1991). It is likely that these factors are playing in the regions with persistently high tariffs, corresponding to lower levels of trade.

The low-low tariff progression regions are the West African Economic and Monetary Union (WAEMU) and the Southern Africa Custom's Union (SACU), which have continuously maintained relatively low MFN rates over the two periods. These RTAs have significantly improved their trade flows due to the application of very low tariff rates among member countries. The SACU, for example, had an average of $8 \% \mathrm{MFN}$ tariff rate over the period 1995 2004, and this rate remained unchanged over the second period (2005 2014). Table 1 shows that intra-SACU trade has increased. Between 1995 and 2004, intra-SACU exports and imports were 1,655,628 US dollars and 4,635,681 US dollars, respectively. These increased considerably to 8,414,595 US dollars and $12,459,928$ US dollars, respectively, in the latter period. The SACU has applied the lowest tariff rates over the two periods. Similarly, the WAEMU region has continuously maintained moderate MFN tariff rates over the two periods. The region had an average of 12\% MFN tariff rate between 1995 and 2004 with intra-regional exports and imports at 1,069,393 US dollars and 858,280 US dollars, respectively. In the second period, these figures increased to 2,468,497 US dollars and 2,381,067 US dollars, respectively. Both SACU and WAEMU have considerably lowered their internal tariff rates over the past 20 years. The intra-WAEMU trade over this period did not substantially improve following a moderate application of tariff rates, whereas the SACU made huge progress in improving its regional trade. Indeed, both regions made great progress in reducing their internal tariffs. 


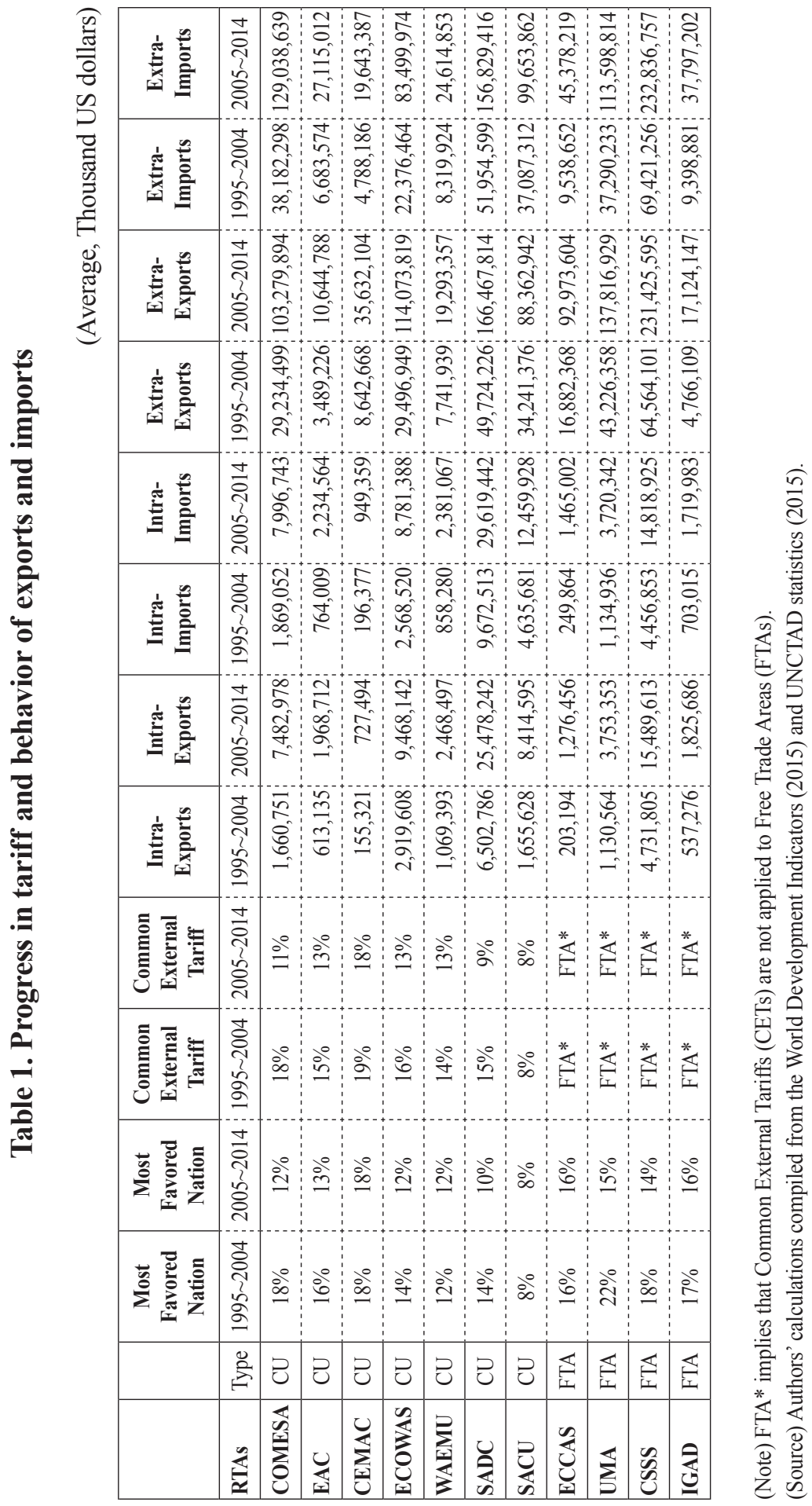




\section{Literature Review}

Since Viner's (1950) influential study showing that customs unions are likely to generate costs due to trade diversion, many studies have embarked on quantifying the effects of RTAs. Early empirical studies relied on cross-sectional data to estimate the gravity model (Anderson 1979, Bergstrand 1985 and 1989, McCallum 1995, Deardorff 1998). These traditional and mostly cross-sectional approaches have been plagued with severe misspecification problems and, thus, are likely to yield unreliable results (Carrerè 2006).

Later studies corrected this bias by employing panel data techniques, mostly in pooled Ordinary Least Square (OLS) estimation frameworks. In this class of studies, Carrere (2004) used an augmented gravity model and found evidence that the RTAs of SADC, COMESA, and ECOWAS have been trade-creating. She argued that trade and currency unions (such as in the CEMAC and the West African Economic and Monetary Union (UEMOA)) appear to be more efficient in stimulating intra-regional trade.

Following this, Musila (2005) investigated the intensity of trade creation and diversion within ECOWAS, ECCAS, and COMESA. He found evidence of the ECOWAS having the highest level of trade creation followed by the COMESA and ECCAS. Some authors have argued that RTAs in Africa may not produce the desired effects due to substantial barriers to intra-African trade that RTAs may not deal with. Longo and Sekkat (2004) identified the key obstacles to be internal political tensions, mismanagement of economic policies, and the lack of infrastructure.

In addition, using a gravity model to assess the expansion possibilities of intraAfrican trade, Longo and Sekkat (2004) identified the major obstacles to be internal political tensions, mismanagement of economic policies, and the lack of infrastructure. Demonstrating how coastal and landlocked countries are substantially affected by the high transport costs associated with poor infrastructure, Limao and Venables (2001) asserted that because trade costs associated with intra-sub-Saharan African trade were significantly larger, trade flows within the region were consequently considerably lower compared with non-sub-Saharan African countries. Africa's great potential to trade has been substantially obstructed due to higher trade costs.

Several studies have criticized the traditional OLS approach in evaluating the trade effects of RTAs because it produces inconsistent coefficient estimates. The OLS approach does not properly address the problems of multicollinearity and sample selection bias, 
especially in cross-sectional data. It also fails to control for unobserved heterogeneity. Following the elimination of zero trade flows, the OLS method leads to loss of efficiency (Martin and Pham 2008, Santos Silva and Tenreyro 2006, 2008, 2009, and 2011, Siliverstovs and Schumacher 2009).

These criticisms have brought to light the merits of the Poisson Pseudo-Maximum Likelihood (PPML) estimator with various fixed effects to deal with heteroscedasticity and zero trade observations. Sun and Reed (2010) used the PPML and found that it was preferred to the OLS when assessing RTA effects in the ASEAN-China preferential trade agreement and the EU-15, EU-25, and SADC agreements. They found that these RTAs have generated large increases in agricultural trade flows among their respective member countries.

Similarly, Santos Silva and Tenreyro (2006) found that in the presence of heteroscedasticity, the standard methods can severely bias the estimated coefficients. As such, they cast doubts on previous empirical findings. They proposed the PPML method as the better alternative, especially in the presence of heteroscedasticity. Furthermore, Santos Silva and Tenreyro (2009) posited that the PPML estimator was well behaved even when the dependent variable had a large proportion of zeros. They argued that the PPML method provided a natural way to deal with the zeros in trade data while providing consistent parameter estimates.

This paper follows the approach of Santos Silva and Tenreyo (2006) to revisit the assessment of the trade effects of RTAs in 11 regional groups in Africa. Another reason for undertaking this work is that most studies that have examined this issue for Africa assume that the effects of RTAs are instantaneous. We control for the duration of each RTA to estimate the extra benefits that are likely to accrue over time.

\section{Methodology}

The gravity model is the basic econometric technique applied in the empirical examination of bilateral trade flows (Lee 1993). In recent years, extensive use of the gravity model has become essential to measure potential levels of bilateral trade. Realworld experience has shown that its application is less complicated to adopt empirically (Baier and Bergstrand 2007). While Bergstrand (1985) argued that the underlying macroeconomic foundations theoretically provide the empirical derivation of the 
gravity model, Learner and Levinsohn (1994), on the other hand, maintained that when compared with the other models, the gravity model is less associated with omitted variable biases and simultaneous biases (double causality) that reduce the efficacy of the estimates in the model. They further established that the gravity model entailed the use of a more consistent database in the empirical assessment of bilateral trade flows (Martinez-Zarzoso 2003).

\section{A. The model}

The gravity model for bilateral trade flows states that bilateral trade $\left(X_{i j}\right)$ between the exporting country (country $i$ ) and the importing country (country $j$ ) is proportional to the product of their GDPs $\left(Y_{i} Y_{j}\right)$ and negatively proportional to the geographic distance $\left(D_{i j}\right)$ between them. The basic gravity model in multiplicative form can be illustrated algebraically as follows:

$$
T_{i j}=\alpha_{0} Y_{i}^{\alpha 1} Y_{j}^{\alpha 2} D_{i j}^{\alpha 3}
$$

Some specifications of the model include the populations of the exporter and the importer $\left(P_{i}\right.$ and $\left.P_{j}\right)$. Anderson and Van Wincoop (2003) re-specified the gravity equation in Equation (1) by introducing the exponent of the sum of various multilateral resistance terms. After log linearization, the major resistance terms enter the equation as a set of dummies mostly for common language $\left(L_{i j}\right)$ and contiguity $\left(C_{i j}\right)$. Taking the logarithm of Equation (1) and introducing the other variables yield the following:

$$
\begin{aligned}
\ln \left(X_{j i t}\right)= & \alpha_{0}+\alpha_{1} \ln \left(Y_{i t}\right)+\alpha_{2} \ln \left(Y_{j t}\right)+\alpha_{3} \ln \left(D_{i j}\right)+\alpha_{4} \ln \left(P_{j t}\right) \\
& +\alpha_{5} \ln \left(P_{i t}\right)+\alpha_{6} L_{i j}+\alpha_{7} C_{i j}+\varepsilon_{i j}
\end{aligned}
$$

where $\alpha_{1}, \alpha_{2}$, and $\alpha_{3}$ are coefficients; $\alpha_{0}$ is the intercept; and $\varepsilon_{i j}$ is the error term. To estimate the effects of RTAs on trade flows, we augment Equation (2) with INTRA dummies, taking 1 if a country pair belongs to the same RTA and 0 otherwise, and EXTRA dummies, taking 1 if the importer is a member of the RTA and the exporter is not and 0 otherwise. The augmentation results are expressed in Equation (3) below: 


$$
\begin{aligned}
& \ln \left(X_{j i t}\right)=\alpha_{0}+\alpha_{1} \ln \left(Y_{i t}\right)+\alpha_{2} \ln \left(Y_{j t}\right)+\alpha_{3} \ln \left(D_{i j}\right)+\alpha_{4} \ln \left(P_{j t}\right)+\alpha_{5} \ln \left(P_{i t}\right)+ \\
& \alpha_{6} L_{i j}+\alpha_{7} C_{i j}+\alpha_{8} I N T R A_{E C C A S}+\alpha_{9} I N T R A_{E A C}+\alpha_{10} I N T R A_{C S S S}+ \\
& \alpha_{11} I_{N T R A_{\text {COMESA }}}+\alpha_{12} \text { INTRA }_{S A D C}+\alpha_{13} I N T R A_{E C O W A S}+ \\
& \alpha_{14} I N T R A_{C E M A C}+\alpha_{15} I N T R A_{U M A}+\alpha_{16} I N T R A_{I G A D}+\alpha_{17} I N T R A_{S A C U}+ \\
& \alpha_{18}{I N T R A_{U E M O A}}+\alpha_{19} E X T R A_{E C C A S}+\alpha_{20} E X T R A_{E A C}+\alpha_{21} E X T R A_{C S S S}+ \\
& \alpha_{22} E_{\text {ETRA }} A_{\text {COMESA }}+\alpha_{23} E X T R A_{S A D C}+\alpha_{24} E X T R A_{E C O W A S}+ \\
& \alpha_{25} E X T R A_{C E M A C}+\alpha_{26} E X T R A_{U M A}+\alpha_{27} E X T R A_{I G A D}+\alpha_{28} E X T R A_{S A C U}+ \\
& \alpha_{29} E X T R A_{U E M O A}+\varepsilon_{i j}
\end{aligned}
$$

Lastly, to capture the extra effects that may occur over time, we introduce time trends to capture the respective durations of the different RTAs. For this, we estimate Equation (4) below:

$$
\begin{aligned}
& \ln \left(X_{j i t}\right)=\alpha_{0}+\alpha_{1} \ln \left(Y_{i t}\right)+\alpha_{2} \ln \left(Y_{j t}\right)+\alpha_{3} \ln \left(D_{i j}\right)+\alpha_{4} \ln \left(P_{j t}\right)+\alpha_{5} \ln \left(P_{i t}\right)+ \\
& \alpha_{6} L_{i j}+\alpha_{7} C_{i j}+\alpha_{8} I N T R A_{E C C A S}+\alpha_{9} I N T R A_{E A C}+\alpha_{10} I N T R A_{C S S S}+ \\
& \alpha_{11}{I N T R A_{\text {COMESA }}}+\alpha_{12} I_{N T R} A_{S A D C}+\alpha_{13} I N T R A_{E C O W A S}+ \\
& \alpha_{14} I N T R A_{C E M A C}+\alpha_{15} I N T R A_{U M A}+\alpha_{16} I N T R A_{I G A D}+\alpha_{17} I N T R A_{S A C U}+ \\
& \alpha_{18} I N T R A_{U E M O A}+\alpha_{19} E X T R A_{E C C A S}+\alpha_{20} E X T R A_{E A C}+\alpha_{21} E X T R A_{C S S S}+ \\
& \alpha_{22} \text { EXTRA }_{\text {COMESA }}+\alpha_{23} \text { EXTRA }_{S A D C}+\alpha_{24} \text { EXTRA }_{\text {ECOWAS }}+ \\
& \alpha_{25} E_{X T R A_{C E M A C}}+\alpha_{26} E X T R A_{U M A}+\alpha_{27} E X T R A_{I G A D}+\alpha_{28} E X T R A_{S A C U}+
\end{aligned}
$$



$$
\begin{aligned}
& \alpha_{33} \text { TCOMESA }_{\text {Exp }}+\alpha_{34} \text { TSADC }_{\text {Exp }}+\alpha_{35} \text { TECOWAS }_{\text {Exp }}+\alpha_{36} \text { TCEMAC } C_{\text {Exp }}+ \\
& \alpha_{37} T_{U M} A_{E x p}+\alpha_{38} \text { TIGAD }_{E x p}+\alpha_{39} T_{S A C U_{E x p}}+\alpha_{40} \text { TUEMOA } A_{\text {Exp }}+\varepsilon_{i j}
\end{aligned}
$$

\section{B. Variables}

The data for our analyses cover 53 African countries from four different sources. Trade data are from the United Nations Conference on Trade and Development (UNCTAD) database. Data on population and GDP are from the World Development Indicators (WDI). Information on common border links, common language, and the geographical distance is sourced from the Centre d'Etudes Prospectives et d'Informations Internationales (CEPII) database. Table 2 provides a summary of the data variables and description. 


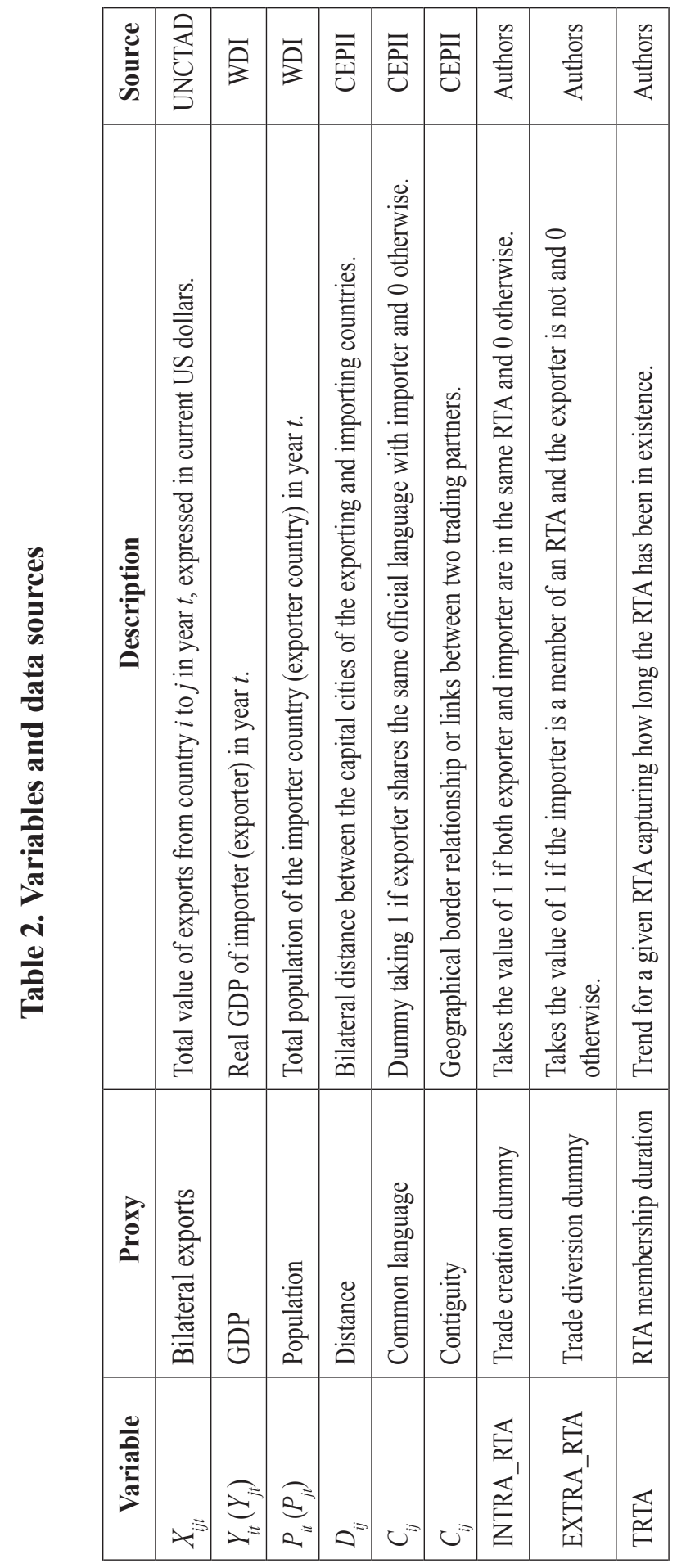




\section{Estimation specification}

A number of approaches have been employed to estimate the gravity model in the past. Application of the traditional OLS method has shown numerous problems, leading to inconsistent coefficient estimates (Santos Silva and Tenreyro 2006). Frankel and Wei (1993), have used the Non-linear Least Square (NLS) technique to address problems of this nature. The main source of heteroscedasticity in the type of the data is that more developed countries tend to have better quality data than less developed ones. Such heterogeneity is expected to be present in African countries' data.

The PPML estimator has emerged as a relatively better alternative. The only condition for consistent estimates is the correct specification of the conditional mean. The gravity model does well in this. For the PPML estimator to do well in the presence of heteroscedasticity, the assumption that the conditional variance should be proportional to the conditional mean (i.e., $\left.V\left(y_{i} \mid x\right) \propto E\left(y_{i} \mid x\right)\right)$ must hold. This is unlikely to hold in our case. We, therefore, based our inference on the Eicker-White robust covariance PPML estimator (Eicker 1963, White 1980). We also employed the Ramsey (1969) Regression Equation Specification Error Test (RESET), which proved that the PPML method was appropriate and the OLS was not.

\section{Results}

The results of the different estimates are reported in Table 3. Model 1 gives the estimates of the basic gravity model in Equation (2). Model 2 gives estimates of the gravity model augmented with dummies for trade creation and diversion in Equation (3). Model 3 captures the results of the full gravity equation with time trends to capture the duration of RTA arrangements in Equation (4). Within each model, the robust OLS (first column) and robust PPML (second column) are presented. Our inference is based on the PPML estimates.

The results vary significantly between the OLS and the PPML. Hence, we implement the heteroscedasticity-robust RESET for each of the estimated models. The RESET method proposed by Ramsey (1969) tests for the appropriate specification of the conditional expectation. The $F$-statistics and probability values of the test are presented 
in the last two rows of Table 3. The test results conclude that the OLS models are inappropriately specified but that the PPML models are correctly specified.

The basic gravity model performs according to expectation, with all the standard variables having the theoretically expected signs. Distance as a proxy for logistics trade cost significantly impedes trade, with a coefficient that is above unity. The GDPs of the two trading partners enhance trade. However, as expected, the GDP of the importing country has a larger effect in magnitude, i.e., greater than unity in most of the models. The population variables have the expected positive signs only in the PPML estimates of the extended gravity models that include the RTA time periods, with the exported population showing a significant effect. Higher trade happens between neighboring country pairs than between non-neighbors and between countries with a common language.

Table 3. Gravity model results

\begin{tabular}{|c|c|c|c|c|c|c|}
\hline Model & \multicolumn{2}{|c|}{ Model 1} & \multicolumn{2}{|c|}{ Model 2} & \multicolumn{2}{|c|}{ Model 3} \\
\hline Estimator & OLS & PPML & OLS & PPML & OLS & PPML \\
\hline Dependent variable & $\ln \left(x_{i j t}\right)$ & $x_{i j t}$ & $\ln \left(x_{i j t}\right)$ & $x_{i j t}$ & $\ln \left(x_{i j t}\right)$ & $x_{i j t}$ \\
\hline \multirow{2}{*}{$\ln \left(\right.$ Dist $\left._{i j}\right)$} & $-1.926^{* * *}$ & $-1.382^{* * *}$ & $-1.648^{* * *}$ & $-1.019^{* * *}$ & $-1.641^{* * *}$ & $-1.138^{* * *}$ \\
\hline & $(0.074)$ & $(0.049)$ & $(0.094)$ & $(0.095)$ & $(0.103)$ & $(0.080)$ \\
\hline \multirow{2}{*}{$\ln \left(G D P_{E x p}\right)$} & $0.599^{* * *}$ & $0.466^{* * *}$ & $0.703^{* * *}$ & $0.699^{* * *}$ & $0.682^{* * *}$ & $0.588^{* * *}$ \\
\hline & $(0.041)$ & $(0.037)$ & $(0.040)$ & $(0.032)$ & $(0.046)$ & $(0.035)$ \\
\hline \multirow{2}{*}{$\ln \left(G D P_{I m p}\right)$} & $1.170^{* * *}$ & $0.994^{* * *}$ & $1.046^{* * *}$ & $0.976^{* * *}$ & $1.062^{* * *}$ & $1.007^{* * *}$ \\
\hline & $(0.042)$ & $(0.032)$ & $(0.048)$ & $(0.034)$ & $(0.048)$ & $(0.034)$ \\
\hline \multirow{2}{*}{$\ln \left(\boldsymbol{P o p}_{E x p}\right)$} & 0.029 & $0.085^{* *}$ & -0.008 & 0.013 & 0.037 & $0.163^{* * *}$ \\
\hline & $(0.046)$ & $(0.041)$ & $(0.043)$ & $(0.040)$ & $(0.051)$ & $(0.042)$ \\
\hline \multirow{2}{*}{$\ln \left(\right.$ Pop $\left._{\text {Imp }}\right)$} & $-0.137^{* * *}$ & -0.058 & 0.070 & 0.081 & 0.060 & 0.066 \\
\hline & $(0.046)$ & $(0.135)$ & $(0.052)$ & $(0.240)$ & $(0.052)$ & $(0.041)$ \\
\hline \multirow{2}{*}{$\begin{array}{l}\text { Contiguity } \\
\text { (Common border links) }\end{array}$} & $1.203^{* * *}$ & $0.383^{* * *}$ & $1.019^{* * *}$ & $0.482^{* * *}$ & $1.023^{* * *}$ & $0.471^{* * *}$ \\
\hline & $(0.184)$ & $(0.085)$ & $(0.162)$ & $(0.069)$ & $(0.165)$ & $(0.058)$ \\
\hline \multirow{2}{*}{ Language } & $0.819^{* * *}$ & $0.353^{* * *}$ & $0.753^{* * *}$ & $0.455^{* * *}$ & $0.738^{* * *}$ & $0.541^{* * *}$ \\
\hline & $(0.095)$ & $(0.070)$ & $(0.090)$ & $(0.064)$ & $(0.089)$ & $(0.057)$ \\
\hline \multirow{2}{*}{ INTRA_ECCAS } & - & - & $-1.363^{* * *}$ & 0.319 & $-1.156^{* * *}$ & 0.140 \\
\hline & - & - & $(0.339)$ & $(0.195)$ & $(0.349)$ & $(0.189)$ \\
\hline
\end{tabular}


(continued)

\begin{tabular}{|c|c|c|c|c|c|c|}
\hline Model & \multicolumn{2}{|c|}{ Model 1} & \multicolumn{2}{|c|}{ Model 2} & \multicolumn{2}{|c|}{ Model 3} \\
\hline Estimator & OLS & PPML & OLS & PPML & OLS & PPML \\
\hline Dependent variable & $\ln \left(x_{i j t}\right)$ & $x_{i j t}$ & $\ln \left(x_{i j t}\right)$ & $x_{i j t}$ & $\ln \left(x_{i j t}\right)$ & $x_{i j t}$ \\
\hline \multirow{2}{*}{ INTRA_EAC } & - & - & $1.883^{* * *}$ & $1.268^{* * *}$ & $2.178^{* * *}$ & $1.502^{* * *}$ \\
\hline & - & - & $(0.319)$ & $(0.115)$ & $(0.359)$ & $(0.158)$ \\
\hline \multirow{2}{*}{ INTRA_CSSS } & - & - & $-0.363^{* * *}$ & $-0.422^{* * *}$ & -0.145 & $-0.306^{* * *}$ \\
\hline & - & - & $(0.100)$ & $(0.085)$ & $(0.118)$ & $(0.093)$ \\
\hline \multirow{2}{*}{$\ln \left(\right.$ Dist $\left._{i j}\right)$} & $-1.926^{* * *}$ & $-1.382^{* * *}$ & $-1.648^{* * *}$ & $-1.019^{* * *}$ & $-1.641^{* * *}$ & $-1.138^{* * *}$ \\
\hline & $(0.074)$ & $(0.049)$ & $(0.094)$ & $(0.095)$ & $(0.103)$ & $(0.080)$ \\
\hline \multirow{2}{*}{$\ln \left(G D P_{E x p}\right)$} & $0.599^{* * *}$ & $0.466^{* * *}$ & $0.703^{* * *}$ & $0.699^{* * *}$ & $0.682^{* * *}$ & $0.588^{* * *}$ \\
\hline & $(0.041)$ & $(0.037)$ & $(0.040)$ & $(0.032)$ & $(0.046)$ & $(0.035)$ \\
\hline \multirow{2}{*}{$\ln \left(G D P_{I m p}\right)$} & $1.170^{* * *}$ & $0.994^{* * *}$ & $1.046^{* * *}$ & $0.976^{* * *}$ & $1.062^{* * *}$ & $1.007^{* * *}$ \\
\hline & $(0.042)$ & $(0.032)$ & $(0.048)$ & $(0.034)$ & $(0.048)$ & $(0.034)$ \\
\hline \multirow{2}{*}{$\ln \left(\boldsymbol{P o p}_{E x p}\right)$} & 0.029 & $0.085^{* *}$ & -0.008 & 0.013 & 0.037 & $0.163^{* * *}$ \\
\hline & $(0.046)$ & $(0.041)$ & $(0.043)$ & $(0.040)$ & $(0.051)$ & $(0.042)$ \\
\hline \multirow{2}{*}{$\ln \left(\boldsymbol{P o p}_{I m p}\right)$} & $-0.137^{* * *}$ & -0.058 & 0.070 & 0.081 & 0.060 & 0.066 \\
\hline & $(0.046)$ & $(0.135)$ & $(0.052)$ & $(0.240)$ & $(0.052)$ & $(0.041)$ \\
\hline \multirow{2}{*}{$\begin{array}{l}\text { Contiguity } \\
\text { (Common border links) }\end{array}$} & $1.203^{* * *}$ & $0.383^{* * *}$ & $1.019^{* * *}$ & $0.482^{* * *}$ & $1.023^{* * *}$ & $0.471^{* * *}$ \\
\hline & $(0.184)$ & $(0.085)$ & $(0.162)$ & $(0.069)$ & $(0.165)$ & $(0.058)$ \\
\hline \multirow{2}{*}{ Language } & $0.819^{* * *}$ & $0.353^{* * *}$ & $0.753^{* * *}$ & $0.455^{\text {*** }}$ & $0.738^{* * *}$ & $0.541^{* * *}$ \\
\hline & $(0.095)$ & $(0.070)$ & $(0.090)$ & $(0.064)$ & $(0.089)$ & $(0.057)$ \\
\hline \multirow{2}{*}{ INTRA_ECCAS } & - & - & $-1.363^{* * *}$ & 0.319 & $-1.156^{* * *}$ & 0.140 \\
\hline & - & - & $(0.339)$ & $(0.195)$ & $(0.349)$ & $(0.189)$ \\
\hline \multirow{2}{*}{ INTRA_EAC } & - & - & $1.883^{* * *}$ & $1.268^{* * *}$ & $2.178^{* * *}$ & $1.502^{* * *}$ \\
\hline & - & - & $(0.319)$ & $(0.115)$ & $(0.359)$ & $(0.158)$ \\
\hline \multirow{2}{*}{ INTRA_CSSS } & - & - & $-0.363^{* * *}$ & $-0.422^{* * *}$ & -0.145 & $-0.306^{* * *}$ \\
\hline & - & - & $(0.100)$ & $(0.085)$ & $(0.118)$ & $(0.093)$ \\
\hline \multirow{2}{*}{ INTRA_COMESA } & - & - & $1.230^{* * *}$ & $1.050^{* * *}$ & $1.548^{* * *}$ & $1.250^{* * *}$ \\
\hline & - & - & $(0.169)$ & $(0.103)$ & $(0.185)$ & $(0.104)$ \\
\hline \multirow{2}{*}{ INTRA_SADC } & - & - & $1.207^{* * *}$ & $1.968^{* * *}$ & $1.146^{* * *}$ & $1.303^{* * *}$ \\
\hline & - & - & $(0.202)$ & $(0.103)$ & $(0.228)$ & $(0.119)$ \\
\hline \multirow{2}{*}{ INTRA_ECOWAS } & - & - & $1.138^{* * *}$ & $2.042^{* * *}$ & $0.751^{* * *}$ & $1.713^{* * *}$ \\
\hline & - & - & $(0.266)$ & $(0.186)$ & $(0.282)$ & $(0.185)$ \\
\hline
\end{tabular}


(continued)

\begin{tabular}{|c|c|c|c|c|c|c|}
\hline Model & \multicolumn{2}{|c|}{ Model 1} & \multicolumn{2}{|c|}{ Model 2} & \multicolumn{2}{|c|}{ Model 3} \\
\hline Estimator & OLS & PPML & OLS & PPML & OLS & PPML \\
\hline Dependent variable & $\ln \left(x_{i j t}\right)$ & $x_{i j t}$ & $\ln \left(x_{i j t}\right)$ & $x_{i j t}$ & $\ln \left(x_{i j t}\right)$ & $x_{i j t}$ \\
\hline \multirow{2}{*}{ INTRA_CEMAC } & - & - & $2.589^{* * *}$ & $1.147^{* * *}$ & $2.455^{* * *}$ & $0.854^{* * *}$ \\
\hline & - & - & $(0.446)$ & $(0.225)$ & $(0.466)$ & $(0.264)$ \\
\hline \multirow{2}{*}{ INTRA_UMA } & - & - & $1.582^{* * *}$ & $1.050^{* * *}$ & $1.541^{* *}$ & $1.301^{* * *}$ \\
\hline & - & - & $(0.592)$ & $(0.149)$ & $(0.618)$ & $(0.152)$ \\
\hline \multirow{2}{*}{ INTRA_IGAD } & - & - & -0.012 & $0.288^{* *}$ & 0.281 & $0.335^{* *}$ \\
\hline & - & - & $(0.372)$ & $(0.134)$ & $(0.387)$ & $(0.131)$ \\
\hline \multirow{2}{*}{ INTRA_SACU } & - & - & 0.497 & $0.446^{* * *}$ & 0.477 & -0.042 \\
\hline & - & - & $(0.361)$ & $(0.131)$ & $(0.374)$ & $(0.144)$ \\
\hline \multirow{2}{*}{ INTRA_UEMOA } & - & - & $1.836^{* * *}$ & $1.038^{* * *}$ & $2.109^{* * *}$ & $0.897^{* * *}$ \\
\hline & - & - & $(0.275)^{-}$ & $(0.121)$ & $(0.295)^{-}$ & $(0.155)$ \\
\hline \multirow{2}{*}{ EXTRA_ECCAS } & - & - & $-1.894^{* * *}$ & -0.159 & $-1.909^{* * *}$ & -0.146 \\
\hline & - & - & $(0.211)$ & $(0.214)$ & $(0.212)$ & $(0.200)$ \\
\hline \multirow{2}{*}{ EXTRA_EAC } & - & - & $0.564^{* * *}$ & 0.048 & $0.608^{* * *}$ & -0.016 \\
\hline & - & - & $(0.144)$ & $(0.092)$ & $(0.146)$ & $(0.096)$ \\
\hline \multirow{2}{*}{ EXTRA_CSSS } & - & - & $-0.582^{* * *}$ & $-0.336^{* * *}$ & $-0.600^{* * *}$ & $-0.409^{* * *}$ \\
\hline & - & - & $(0.092)$ & $(0.084)$ & $(0.093)$ & $(0.088)$ \\
\hline \multirow{2}{*}{ EXTRA_COMESA } & - & - & $0.672^{* * *}$ & $0.285^{* * *}$ & $0.471^{* * *}$ & 0.143 \\
\hline & - & - & $(0.145)$ & $(0.098)$ & $(0.153)$ & $(0.093)$ \\
\hline \multirow{2}{*}{ EXTRA_SADC } & - & - & $0.369^{* *}$ & $0.440^{* * *}$ & $0.470^{* * *}$ & $0.377^{* * *}$ \\
\hline & - & - & $(0.154)$ & $(0.093)$ & $(0.157)$ & $(0.099)$ \\
\hline \multirow{2}{*}{ EXTRA_ECOWAS } & - & - & $0.542^{* *}$ & $1.337^{* * *}$ & $0.726^{* * *}$ & $1.119^{* * *}$ \\
\hline & - & - & $(0.226)$ & $(0.164)$ & $(0.227)$ & $(0.147)$ \\
\hline \multirow{2}{*}{ EXTRA_CEMAC } & - & - & $2.686^{* * *}$ & $0.612^{* * *}$ & $2.674^{* * *}$ & $0.456^{* *}$ \\
\hline & - & - & $(0.285)$ & $(0.233)$ & $(0.281)$ & $(0.213)$ \\
\hline \multirow{2}{*}{ EXTRA_UMA } & - & - & $1.570^{* * *}$ & $0.460^{* * *}$ & $1.530^{* * *}$ & $0.304^{* *}$ \\
\hline & - & - & $(0.236)$ & $(0.126)$ & $(0.232)$ & $(0.138)$ \\
\hline \multirow{2}{*}{ EXTRA_IGAD } & - & - & $-0.739^{* * *}$ & 0.022 & $-0.761^{* * *}$ & -0.176 \\
\hline & - & - & $(0.192)$ & $(0.119)$ & $(0.191)$ & $(0.124)$ \\
\hline \multirow{2}{*}{ EXTRA_SACU } & - & - & $1.1563^{* * *}$ & $0.7266^{* * *}$ & $1.1384^{* * *}$ & $1.0229^{* * *}$ \\
\hline & - & - & $(0.203)$ & $(0.122)$ & $(0.204)$ & $(0.105)$ \\
\hline \multirow{2}{*}{ EXTRA_UEMOA } & - & - & $1.172^{* * *}$ & $0.555^{* * *}$ & $1.086^{* * *}$ & $0.767^{* * *}$ \\
\hline & - & - & $(0.162)$ & $(0.112)$ & $(0.159)$ & $(0.118)$ \\
\hline \multirow{2}{*}{ TECCAS_Exports } & - & - & - & - & -0.000 & 0.000 \\
\hline & - & - & - & - & $(0.0001)$ & $(0.0000)$ \\
\hline \multirow{2}{*}{ TEAC_Exports } & - & - & - & - & -0.0001 & $-0.0002^{* * *}$ \\
\hline & - & - & - & - & $(0.0001)$ & $(0.0001)$ \\
\hline
\end{tabular}


(continued)

\begin{tabular}{|c|c|c|c|c|c|c|}
\hline Model & \multicolumn{2}{|c|}{ Model 1} & \multicolumn{2}{|c|}{ Model 2} & \multicolumn{2}{|c|}{ Model 3} \\
\hline Estimator & OLS & PPML & OLS & PPML & OLS & PPML \\
\hline Dependent variable & $\ln \left(x_{i j t}\right)$ & $x_{i j t}$ & $\ln \left(x_{i j t}\right)$ & $x_{i j t}$ & $\ln \left(x_{i j t}\right)$ & $x_{i j t}$ \\
\hline \multirow{2}{*}{ TCSSS_Exports } & - & - & - & - & $-0.0001^{* *}$ & 0.0000 \\
\hline & - & - & - & - & $(0.0000)$ & $(0.0000)$ \\
\hline \multirow{2}{*}{ TCOMESA_Exports } & - & - & - & - & $-0.0002^{* * *}$ & -0.0000 \\
\hline & - & - & - & - & $(0.0001)$ & $(0.0000)$ \\
\hline \multirow{2}{*}{ TSADC_Exports } & - & - & - & - & 0.0001 & $0.0002^{* * *}$ \\
\hline & - & - & - & - & $(0.0001)$ & $(0.0001)$ \\
\hline \multirow{2}{*}{ TECOWAS_Exports } & - & - & - & - & $-0.0003^{* *}$ & 0.0000 \\
\hline & - & - & - & - & $(0.0001)$ & $(0.0001)$ \\
\hline \multirow{2}{*}{ TCEMAC_Exports } & - & - & - & - & 0.0001 & $0.0003^{* * *}$ \\
\hline & - & - & - & - & $(0.0001)$ & $(0.0001)$ \\
\hline \multirow{2}{*}{ TUMA_Exports } & - & - & - & - & 0.0000 & -0.0000 \\
\hline & - & - & - & - & $(0.0001)$ & $(0.0001)$ \\
\hline \multirow{2}{*}{ TIGAD_Exports } & - & - & - & - & -0.0001 & -0.0000 \\
\hline & - & - & - & - & $(0.0001)$ & $(0.0001)$ \\
\hline \multirow{2}{*}{ TSACU_Exports } & - & - & - & - & 0.0000 & $0.0005^{* * *}$ \\
\hline & - & - & - & - & $(0.0001)$ & $(0.0001)$ \\
\hline \multirow{2}{*}{ TUEMOA_Exports } & - & - & - & - & $-0.0002^{* * *}$ & $0.0002^{* *}$ \\
\hline & - & - & - & - & $(0.0001)$ & $(0.0001)$ \\
\hline \multirow{2}{*}{ Constant } & $4.864^{* * *}$ & $5.826^{* * *}$ & 1.458 & -0.819 & 1.452 & 0.223 \\
\hline & $(0.679)$ & $(0.443)$ & $(0.881)$ & $(0.857)$ & $(0.951)$ & $(0.636)$ \\
\hline $\mathbf{N}$ & 24,637 & 24,663 & 24,637 & 24,663 & 24,637 & 24,663 \\
\hline$R^{2}$ & 0.45 & 0.33 & 0.51 & 0.62 & 0.51 & 0.67 \\
\hline Ramsey: $F$-statistics & 70.54 & 4.53 & 240.98 & 1.51 & 238.82 & 0.02 \\
\hline Ramsey: $P$-value & 0.000 & 0.033 & 0.000 & 0.218 & 0.000 & 0.902 \\
\hline
\end{tabular}

(Note) $* * *$, and $* * *$ denote significance at $10 \%, 5 \%$, and $1 \%$, respectively. Heteroscedastic-consistent standard errors are in parentheses.

There is no significant evidence of trade creation or trade diversion in the ECCAS. The intra and extra coefficients are both insignificant, suggesting that RTAs have no trade effects in this sub-region. Intra-regional trade within the CSSS falls because of RTA formation. However, trade between members and non-members falls equally. Belonging to the CSSS is estimated to reduce bilateral trade flows within the region by $34 \%$ and reduce trade with non-members by $29 \%$. This suggests that RTAs have a negative impact on trade in the region. There is pure trade creation in the IGAD as the coefficient of the 
intra-trade dummy is both positive and significant. Belonging to the IGAD increases the exports of a member to the region by $33 \%$. However, there is a negative coefficient on the extra dummy. This implies some trade diversion potential, but it is insignificant. The EAC brings about a 3.5 times increase in its intra-trade without a significant change in the trade between members and non-members.

Apart from these four sub-regions, the remaining seven sub-regions assessed record significant trade creation, with a simultaneous increase in trade with non-RTA members. This means that in the majority of African regional integration groupings, RTAs not only bring about intra-regional trade but also simultaneously boost trade with the rest of the world. The highest trade creation effect of RTAs is in the ECOWAS. ECOWAS increases internal trade around eightfold compared with non-members. It also results in about a fourfold increase in trade between members and non-members. The next sub-region with the highest trade effects of RTAs is the SADC. The SADC increases its internal trade by about sevenfold and increases trade with non-members by about $55 \%$. The CEMAC results in about three times more trade with member states compared with non-member states. Its creation has also increased trade between members and non-members by about $84 \%$. The UMA creates about 2.9 times more trade among its member countries compared with non-members. However, it also results in 58\% more trade between its members and non-members. The COMESA creates about 2.9 times more trade among member countries compared with non-members. It also brings about 33\% more trade between its members and the rest of the world. The UEMOA enhances its internal trade 2.8 times and contributes to $74 \%$ more trade between its members and non-members. The SACU creates $56 \%$ more trade among its members. This region brings about greater trade gains with non-members than members and about two times more trade between its members and non-members. We believe this dynamic is largely driven by the SADC, in which SACU is subsumed. If this is true, then it begs the question of the relevance of the SACU within the SADC.

To test for the dynamic effects of RTAs on trade flows, we introduced time trends that captured the duration of the different RTAs. Small but significant dynamic effects were detected in the EAC, SADC, CEMAC, SACU, and UEMOA. Over time, trade in the EAC decreased by $0.0002 \%$ and increased in the SADC and UEMOA by $0.0002 \%$. The increase was $0.0003 \%$ and $0.005 \%$ for CEMAC and SACU, respectively. From these figures, one would conclude that most of the trade gains due to RTAs in Africa might be expected to happen instantaneously and that negligible extra gains over time should be expected. 


\section{Conclusions}

This study employs the Eicker-White robust covariance PPML estimator (Eicker 1963, White 1980) to draw inference on the trade effects of RTAs in Africa. This method proves superior to the usual nonlinear least square estimators, especially against heteroscedasticity and data with zero value. The Ramsey (1969) RESET confirms our choice of the PPML over the OLS. We assessed the trade effects of 11 RTAs in Africa with data spanning 1995 2014.

The findings established no significant evidence of trade diversion in the ECCAS. We also established that both intra-regional trade and trade between members and nonmembers of the CSSS fall because of the formation of the RTA. We found pure trade creation in the IGAD. The EAC significantly increased its intra-trade without any effect on the trade between members and non-members.

In the rest of the seven analyzed RTAs, there is strong evidence of significant trade creation among the respective members accompanied by a significant increase in trade between members and non-members. The highest effects were detected in the ECOWAS followed by the SADC. The remaining in descending order are the CEMAC, UMA, COMESA, and UEMOA. The SACU brings about greater trade gains with non-members than with members. Controlling for the dynamic effects of RTAs using the time trend of RTA durations showed that only a very small but significant effect could be expected to happen over time in the EAC, SADC, CEMAC, SACU, and UEMOA. Most of the trade gains due to RTAs in Africa might be expected to happen instantaneously.

The policy implication of these findings is significant in relation to encouraging regionalism in Africa in terms of commitments and actions. Intra-African trade is still disturbingly low. As of 2018, NEPAD still flags this issue in its website as a key challenge to Africa's development. It shows that only 10 to $12 \%$ of Africa's trade is within Africa, compared to $40 \%$ and $60 \%$ for North America and Western Europe respectively. It is comforting to conclude that African RTAs are trade-creating in most of the sub-regions but equally provide a platform for non-members to increasingly trade in these regions. This conclusion stems from the finding that overall, African RTAs create trade amongst member-states without diverting trade with non-members.

Therefore, RTAs are not only a means to enhance intra-African trade but also a way to foster trade between African RTAs and the rest of the world. It is also worth mentioning that the regions with the greatest trade gains following RTAs, both in terms of intra- 
regional trade creation and trade enhancement with non-member countries, are those that have made significant progress in dismantling tariff barriers. Consequently, we can say that there is still more potential of RTAs trapped in the lack of progress in removing both tariff and non-tariff barriers within African RTAs.

Received 13 August 2017, Revised 02 January 2018, Accepted 14 February 2018

\section{References}

Anderson, James E. "A Theoretical Foundation for The Gravity Equation." The American Economic Review 69, No. 1 (1979): 106-116.

Baier, Scott L., and Jeffrey H. Bergstrand. "Do Free Trade Agreements Actually Increase Members' International Trade?” Journal of International Economics 71, No. 1 (2007): 72-95.

Baldwin, R. "Measurable Dynamic Gains from Trade" National Bureau of Economic Research, No. w3147 (1989)

Bergstrand, Jeffrey H. "The Gravity Equation in International Trade: Some Microeconomic Foundations and Empirical Evidence." The Review of Economics and Statistics (1985): 474-481. 
Bergstrand, Jeffrey H. "The Generalized Gravity Equation, Monopolistic Competition, and The Factor-Proportions Theory in International Trade." The Review of Economics and Statistics (1989): 143-153.

Bhagwati J, \& Panagariya A. "Preferential Trading Areas and Multilateralism: Strangers, Friends or Foes", in The Economics Of Preferential Trade Agreements, Bhagwati J, Panagariya A (Eds). AEI Press: Washington DC (1996):1-78.

Carrère, Céline. "African Regional Agreements: Impact on Trade with or without Currency Unions.” Journal of African Economies 13, No. 2 (2004): 199-239.

Carrere, Céline. "Revisiting the Effects of Regional Trade Agreements on Trade Flows with Proper Specification of the Gravity Model.” European Economic Review 50, No. 2 (2006): 223-247.

De Melo, J., \& Tsikata, Y. "Regional Integration in Africa: Challenges and Prospects". World Institute for Development Economic Research (UNU-WIDER), No. 37 (2015).

Deardorff, Alan. "Determinants of Bilateral Trade: Does Gravity Work in a Neoclassical World?" in the Regionalization of the World Economy, University of Chicago Press, (1998): 7-32.

Eicker, Friedhelm. "Asymptotic Normality and Consistency of the Least Squares Estimators for families of Linear Regressions." The Annals of Mathematical Statistics 34, No. 2 (1963): 447-456.

Frankel, Jeffrey A., and Shang-Jin Wei. "Trade Blocs and Currency Blocs" NBER Working Paper No. 4335 (1993)

Goldberg, Pinelopi K., and Nina Pavcnik. Trade, Inequality, and Poverty: What Do We Know? Evidence from recent Trade Liberalization Episodes in Developing Countries. No. W10593. National Bureau of Economic Research, 2004. 
Huff, Karen. "Developing Country Concerns and Multilateral Trade Negotiations." CATRN Paper 2, Canadian Agricultural Network - Food Trade Research (2000).

Kahnert, Friedrich. "Economic Integration among Developing Countries.” Economic Integration Among Developing Countries. (1969)

Leamer, Edward E., and James Levinsohn. International Trade Theory: The Evidence', NBER, Working Paper, No. W4940. National Bureau of Economic Research, 1994.

Lee, Jong-Wha. "International Trade, Distortions, and Long-Run Economic Growth.” Staff Papers 40, No. 2 (1993): 299-328.

Limao, Nuno, and Anthony J. Venables. "Infrastructure, Geographical Disadvantage, Transport Costs, and Trade." The World Bank Economic Review 15, No. 3 (2001): 451479.

Longo, Robert, and Khalid Sekkat. "Economic Obstacles to Expanding Intra-African Trade." World Development 32, No. 8 (2004): 1309-1321.

Magee, Christopher SP. "New Measures of Trade Creation and Trade Diversion.” Journal of International Economics 75, No. 2 (2008): 349-362.

Martin, Will J., and Cong Si Pham. "Estimating the Gravity Model When Zero Trade Flows are Frequent”. World Bank Manuscript, 2008

Martinez-Zarzoso, Inmaculada. "Gravity Model: An Application to Trade Between Regional Blocs.” Atlantic Economic Journal 31, No. 2 (2003): 174-187.

Mccallum, John. "National Borders Matter: Canada-US Regional Trade Patterns." The American Economic Review 85, No. 3 (1995): 615-623. 
Musila, Jacob Wanjala. "The Intensity of Trade Creation and Trade Diversion in COMESA, ECCAS and ECOWAS: A Comparative Analysis." Journal of African Economies 14, No. 1 (2005): 117-141.

Njinkeu, Dominique, and Bruno Powo Fosso. "Intra-African Trade and Regional Integration." in Prepared for The ADB/AERC International Conference on Accelerating Africa's Development Five Years into The Twenty-First Century: Tunis, Vol. 22, P. 24. (2006).

Ogunkola, E. Olawale. "An Empirical Evaluation of Trade Potential in The Economic Community Of West African States.” AERC Research Paper No. 84 (1998).

Omilola, Babatunde. "To What Extent are Regional Trade Arrangements in Africa fulfilling the Conditions for Successful RTAs?" Journal of African Studies and Development 3, No. 6 (2011): 105-113.

Ramsey, James Bernard. "Tests for Specification Errors in Classical Linear LeastSquares Regression Analysis." Journal of The Royal Statistical Society. Series B (Methodological) (1969): 350-371.

Silva, JMC Santos, And Silvana Tenreyro. "The Log of Gravity." The Review of Economics and Statistics 88, No. 4 (2006): 641-658.

Silva, João Santos, and Silvana Tenreyro. Trading Partners and Trading Volumes: Implementing the Helpman-Melitz-Rubinstein Model Empirically. Centre For Economic Performance, London School of Economics and Political Science, 2009.

Silva, JMC Santos, and Silvana Tenreyro. "Further Simulation Evidence on The Performance of The Poisson Pseudo-Maximum Likelihood Estimator." Economics Letters 112, No. 2 (2011): 220-222.

Silva, J. M. C. S., and S. Tenreyro. "Comments On" The Log of Gravity Revisited"." Manuscript, London School of Economics (2008). 
Siliverstovs, Boriss, and Dieter Schumacher. "Estimating Gravity Equations: To Log or Not To Log?" Empirical Economics 36, No. 3 (2009): 645-669.

Sun, Lin, and Michael R. Reed. "Impacts of Free Trade Agreements on Agricultural Trade Creation and Trade Diversion." American Journal of Agricultural Economics 92, No. 5 (2010): 1351-1363.

Viner, Jacob. "The Economics of Customs Unions." The Customs Union Issue (1950): 41-81.

Wacziarg, Romain. "Measuring the Dynamic Gains from Trade." The World Bank Economic Review 15, No. 3 (2001): 393-429.

White, Halbert. "A Heteroskedasticity-Consistent Covariance Matrix Estimator and A Direct Test for Heteroskedasticity." Econometrica: Journal of The Econometric Society (1980): 817-838.

Winters, L. Alan, Neil Mcculloch, and Andrew Mckay. "Trade Liberalization and Poverty: The Evidence So Far.” Journal of Economic Literature 42, No. 1 (2004): 72115. 


\section{Appendices}

\section{Appendix 1: Membership of African Regional Trade Arrangements}

\begin{tabular}{|c|c|c|c|}
\hline Regional Trade Agreements & $\begin{array}{c}\text { Year } \\
\text { Formed }\end{array}$ & Type & Member Countries \\
\hline $\begin{array}{l}\text { Economic Community of } \\
\text { Central African States (ECCAS) }\end{array}$ & 1983 & $\begin{array}{c}\text { Free Trade } \\
\text { Area }\end{array}$ & $\begin{array}{l}\text { Angola, Burundi, Cameroon, Central African } \\
\text { Republic, Congo Republic, Democratic Re- } \\
\text { public of Congo, Gabon, Equatorial Guinea, } \\
\text { Chad, Rwanda, Sao Tome and Principe }\end{array}$ \\
\hline $\begin{array}{l}\text { Economic and Monetary } \\
\text { Community of Central Africa } \\
\text { (CEMAC) }\end{array}$ & 1994 & $\begin{array}{l}\text { Customs } \\
\text { Union }\end{array}$ & $\begin{array}{l}\text { Gabon, Cameroon, Central African Republic, } \\
\text { Chad, Congo Republic, Equatorial Guinea }\end{array}$ \\
\hline Arab Maghreb Union (UMA) & 1989 & $\begin{array}{c}\text { Free Trade } \\
\text { Area }\end{array}$ & $\begin{array}{l}\text { Algeria, Libya, Mauritania, Morocco, } \\
\text { Tunisia }\end{array}$ \\
\hline $\begin{array}{l}\text { Community of Sahel-Saharan } \\
\text { States (CEN-SAD/CSSS) }\end{array}$ & 1998 & $\begin{array}{c}\text { Free Trade } \\
\text { Area }\end{array}$ & $\begin{array}{l}\text { Benin, Burkina Faso, Central African Repub- } \\
\text { lic, Chad, Comoros, Côte d'Ivoire, Djibouti, } \\
\text { Egypt, Eritrea, Ethiopia, Gambia, Ghana, } \\
\text { Guinea, Guinea-Bissau, Kenya, Liberia, } \\
\text { Libya, Mali, Mauritania, Morocco, Niger, } \\
\text { Nigeria, Senegal, Sierra Leone, Somalia, Sao } \\
\text { Tome and Principe, Sudan, Togo, Tunisia }\end{array}$ \\
\hline $\begin{array}{l}\text { Common Market for Eastern } \\
\text { and Southern Africa } \\
\text { (COMESA) }\end{array}$ & 1994 & $\begin{array}{l}\text { Customs } \\
\text { Union }\end{array}$ & $\begin{array}{l}\text { Burundi, Comoros, Congo DRC, Djibouti, } \\
\text { Egypt, Eritrea, Ethiopia, Kenya, Libya, Mad- } \\
\text { agascar, Malawi, Mauritius, Rwanda, Sudan, } \\
\text { Swaziland, Seychelles, Uganda, Zambia, } \\
\text { Zimbabwe }\end{array}$ \\
\hline $\begin{array}{l}\text { Economic Community of West } \\
\text { African States (ECOWAS) }\end{array}$ & 1975 & $\begin{array}{l}\text { Customs } \\
\text { Union }\end{array}$ & $\begin{array}{l}\text { Benin, Burkina Faso, Côte d'Ivoire, Gambia, } \\
\text { Ghana, Guinea, Guinea-Bissau, Liberia, } \\
\text { Mali, Niger, Nigeria, Senegal, Sierra Leone, } \\
\text { Togo, Cape Verde, Mauritania (withdrawn in } \\
\text { 2000) }\end{array}$ \\
\hline $\begin{array}{l}\text { Southern African Development } \\
\text { Community (SADC) }\end{array}$ & 1992 & $\begin{array}{l}\text { Customs } \\
\text { Union }\end{array}$ & $\begin{array}{l}\text { Angola, Botswana, Democratic Republic } \\
\text { of Congo, Lesotho, Madagascar, Malawi, } \\
\text { Mauritius, Mozambique, Namibia, } \\
\text { Seychelles, South Africa, Swaziland, } \\
\text { Tanzania, Zambia, Zimbabwe }\end{array}$ \\
\hline
\end{tabular}


(continued)

\begin{tabular}{|l|c|c|l|}
\hline Regional Trade Agreements & $\begin{array}{c}\text { Year } \\
\text { Formed }\end{array}$ & Type & \multicolumn{1}{|c|}{ Member Countries } \\
\hline $\begin{array}{l}\text { Inter-Governmental Authority } \\
\text { on Development (IGAD) }\end{array}$ & 1996 & $\begin{array}{c}\text { Free Trade } \\
\text { Area }\end{array}$ & $\begin{array}{l}\text { Djibouti, Ethiopia, Eritrea, Kenya, Somalia, } \\
\text { South Sudan, Sudan, Uganda }\end{array}$ \\
\hline East African Community (EAC) & 2000 & $\begin{array}{c}\text { Customs } \\
\text { Union }\end{array}$ & Kenya, Tanzania, Uganda, Rwanda, Burundi \\
\hline $\begin{array}{l}\text { Southern African Customs } \\
\text { Union (SACU) }\end{array}$ & 1910 & $\begin{array}{c}\text { Customs } \\
\text { Union }\end{array}$ & $\begin{array}{l}\text { South Africa, Botswana, Namibia, Lesotho, } \\
\text { Swaziland }\end{array}$ \\
\hline $\begin{array}{l}\text { West African Economic and } \\
\text { Monetary Union (UEMOA) }\end{array}$ & 1994 & $\begin{array}{c}\text { Customs } \\
\text { Union }\end{array}$ & $\begin{array}{l}\text { Benin, Burkina Faso, Côte d'Ivoire, Mali, } \\
\text { Niger, Senegal, Togo, Guinea-Bissau }\end{array}$ \\
\hline
\end{tabular}

\section{Appendix 2: Interpreting RTA dummies}

\begin{tabular}{|c|c|c|}
\hline \multirow{2}{*}{ Dummy Variable } & + & \multicolumn{2}{|c|}{ Sign } \\
\cline { 2 - 3 } & + & Trade creation \\
\hline \multirow{2}{*}{ INTRA_RTA } & $\begin{array}{c}\text { Trade creation, if EXTRA_RTA }>0 \\
\text { Trade diversion, if EXTRA_RTA }<0\end{array}$ & Trade diversion \\
\hline EXTRA_RTA & Trade creation & Tr \\
\hline
\end{tabular}

